\title{
Konsep Homeschooling Dalam Perspektif Pendidikan Islam
}

\author{
Hairus Sodik
}

Sekolah Tinggi Ilmu Tarbiyah Aqidah Usymuni, Tarate Pandian Sumenep

\begin{abstract}
Abstrak
Homeschooling is essentially a directed educational process carried out by parents or families of their children with a conducive teaching and learning process. Either by using a single type of homeschooling, compound homeschooling, and community homeschooling. In Islam, the learning process of the homeschooling model carried out by parents or family is common. In fact, Islam very firmly gives the responsibility of Islamic education to parents. Parents are first and foremost giving education to their children in a good direction so that they are guided into children who can be proud of in the future before God
\end{abstract}

Keywords: Homeschooling, Islam, education

Homeschooling pada hakekatnya merupakan proses pendidikan terarah yang dilakukan oleh orang tua atau keluarga terhadap anak-anaknya dengan proses belajar mengajar yang kondusif. Baik dengan menggunakan jenis homeschooling tunggal, homeschooling majemuk, dan homeschooling komunitas. Dalam Islam, proses pembelajaran model homeschooling yang dilakukan oleh orang tua atau keluarga sudah biasa dilakukan. Bahkan, Islam dengan sangat tegas memberikan tanggung jawab pendidikan Islam kepada orang tua. Orang tualah yang paling pertama dan utama memberikan pendidikan pada putra-putrinya ke arah yang baik agar mereka terbimbing menjadi anak-anak yang dapat dibanggakan kelak di hadapan Allah SWT.

Kata Kunci : Homeschooling, Islam, dan Pendidikan 


\section{Pendahuluan}

Istilah homeschooling akhir-akhir ini sudah mulai akrab di telinga. Homeschooling di Indonesia sering dikaitkan dengan selebritas, yang karena kesibukannya lebih memilih keluar dari sekolah formal dan menjalani homeschooling, dan tentunya jam belajar bisa disusun dan disesuaikan sendiri sesuai dengan jadwal dan kesibukannya.

Hal inilah yang membuat kabur tentang pengertian homeschooling, dan dianggap sebagai bentuk pendidikan yang sangat eksklusif dan diperuntukkan bagi kalangan tertentu saja. Padahal homeschooling bisa dijalani oleh siapa saja yang mau mendidik anaknya dengan cara dan pola homeschooling. Dari itulah kita harus memahami makna sebenarnya dari homeschooling itu.

Istilah homeschooling berasal dari bahasa Inggris berarti sekolah rumah. ${ }^{1}$ Homeschooling berakar dan tumbuh di Amerika Serikat, yang dikenal juga dengan sebutan Home Education, Home Based Learning atau sekolah mandiri. ${ }^{2}$

Homeschooling adalah proses layanan pendidikan yang secara sadar, teratur dan terarah dilakukan oleh orang tua atau keluarga di rumah atau tempat-tempat lain dengan penuh tanggung jawab. Proses belajar mengajar dapat berlangsung dalam suasana yang kondusif dengan tujuan agar setiap potensi anak yang unik dapat berkembang secara maksimal.3

\footnotetext{
1 Indah Hanaco, I Love Homeschooling, Segala Sesuatu yang Harus Diketahui Tentang Homeschooling (Jakarta: PT. Gramedia Pustaka Utama, 2012), 3

2 Sumardiono, "Homeschooling A Lear For Better Learning”, dalam http:

//www.sumardiono.com. (15 Maret 2012)

3 Suryadi dalam Zulliza Istiani, Skripsi Penerapan Jenis Homeschooling Dalam Pembentukan Kemandirian Anak (Malang: UIN Malang, 2008), 8
} 
Saputra mengartikan bahwa homeschooling sebagai proses layanan pendidikan yang secara sadar dan terarah yang dilakukan oleh orang tua atau keluarga dengan proses belajar mengajar yang kondusif.4

Pengertian umum homeschooling adalah model pendidikan dimana sebuah keluarga memilih untuk bertanggung jawab sendiri atas pendidikan anaknya dengan menggunakan rumah sebagai basis pendidikannya yang berarti orang tua terlibat langsung menentukan proses penyelenggaraan pendidikan, penentuan arah dan tujuan pendidikan, nilai-nilai yang hendak dikembangkan, kecerdasan keterampilan, kurikulum dan materi, serta metode dan praktek belajar.5

Hal penting yang mendasari homeschooling adalah pendidikan dilaksanakan sendiri oleh keluaraga, difokuskan pada kepentingan dan kebutuhan anak, dengan tujuan untuk mengembangkan potensi anak semaksimal mungkin.6 Pada hakekatnya homeschooling merupakan sebuah sekolah alternatif yang mencoba menempatkan anak sebagai subjek belajar dengan pendekatan pendidikan secara at home. Pendekatan pendidikan secara at home yaitu suatu pendekatan kekeluargaan yang memungkinkan anak belajar dengan nyaman sesuai dengan keinginan dan gaya belajar masing-masing, kapan saja, dimana saja dan dengan siapa saja.7

Seorang ibu merawat anak-anaknya, mengajari mereka tentang nama-nama benda di rumah, mengajari cara menggunakan peralatan makan, melatih mereka untuk bisa memakai baju, mengajari membaca doa, memakai sepatu, dan sangat banyak ilmu yang diajarkan Ibu pada

\footnotetext{
4 Saputra, Abe. A. Rumahku Sekolahku. Panduan Bagi Orang Tua Untuk Menciptakan Homeschooling: (Yogyakarta: Graha Pustaka, 2007), 23

${ }^{5}$ Sumardiono H. Home Schooling A Lear For Better Learning. (15 Maret 2012)

6 3Indah hanaco, I Love Homschooling, 5

7 Seto Mulyadi, Homeschooling Keluarga Kak-Seto: Mudah, Murah, Meriah, dan Direstui Pemerintah. (Bandung: Kaifa PT Mizan Pustaka, 2007), 9
} 
anak-anaknya. Secara garis besar homeschooling adalah perpanjangan dari proses itu. Ibu sesungguhnya telah melaksanakan homeschooling sejak anak-anak lahir ke dunia. Proses luar biasa yang tidak pernah disadari ibu sebelumnya yang telah mengantarkan anak-anaknya menjadi mengerti banyak hal di dunia ini.

Jadi, secara sederhana homeschooling bisa dijelaskan sebagai sebagai model pendidikan berbasis rumah, dengan orang tua sebagai penanggung jawab aktif secara fokus pada kepentingan dan kebutuhan anak-anaknya. 8

Homeschooling merupakan salah satu bentuk pendidikan alternatif yang berlandaskan teori pendidikan kepribadian (humanistik). Pendidikan kepribadian merupakan konsep pendidikan yang lebih menekankan pada proses pengembangan kemampuan siswa. Materi ajaran dipilih yang sesuai dengan minat, kemampuan dan kebutuhan siswa.9 Dengan pendekatan ini diharapkan anak bisa tumbuh kembang secara lebih wajar dan optimal tanpa terkekang potensinya.

Homeschooling bukanlah sekolah formal atau lembaga. Orang tualah yang melaksanakan homeschooling dengan mengatur polanya sendiri. Namun dalam perjalanannya, orang tua dapat bekerja sama dengan lembaga lainnya untuk memperlancar proses homeschooling.10 Jadi terserah pada keluarga untuk memilih mana homeschooling yang dirasa cocok untuk anak-anaknya.

Walaupun demikian, orang tua sebagai penanggung jawab atas pendidikan anaknya, dalam pelaksanaan homeschooling orang tua tidak harus sepenuhnya turun tangan langsung dengan berperan sebagai

\footnotetext{
8 Indah Hanaco, I Love Homeschooling, 5

${ }^{9}$ Ali Muhtadi, Pendidikan dan Pembelajaran, 16

${ }^{10}$ Indah hanaco, I Love Homeschooling, 6
} 
pendidik karena kesibukannya.11 Oleh karena itu, homeschooling sekarang berkembang sesuai dengan kebutuhan keluarga yang membutuhkan pendidikan anakanya secara khusus. Homeschooling menjadi salah satu alternatif untuk keluarga yang menginginkan anakanak mereka tetap belajar optimal tapi tetap selalu merasa nyaman dan dalam pantauan keluarga atau orang tua.

\section{Tujuan Homeschooling}

Setiap pembelajaran yang dilaksanakan harus memiliki tujuan yang tepat, sehingga dapat mencapai hasil belajar yang maksimal. Namun Ada beberapa persyaratan yang perlu dipenuhi para orang tua yang ingin melaksanakan model pendidikan homeschooling agar berjalan sesuai dengan tujuan pendidikan homeschooling itu sendiri, antara lain yaitu: (1) mencintai anak-anak, (2) kreatif, (3) sabar dan bersahabat dengan anak, (4) memahami kebutuhan dan keinginan anak, (5) mengetahui kemampuan dan ketertarikan anak, (6) mau mendengar dan bernegosiasi, (7) mau berubah, fleksibel, dan tanggap, (8) memahami kondisi fisik, psikis, dan mood anak, (9) memiliki komitmen waktu untuk belajar bersama anak. ${ }^{12}$

Mulyadi, juga menegaskan bahwa homeschooling memiliki tujuan :

a. Menciptakan lingkungan belajar yang kondusif, menyenangkan dan menantang bagi anak didik sesuai dengan kepribadian, gaya belajar, kekuatan dan keterbatasan yang dimilikinya.

b. Mempelajari materi pelajaran secara langsung dalam konteks kehidupan nyata sehingga lebih bermakna dan berguna dalam kehidupan anak didik.

11 Satmoko Budi Santoso, Sekolah Alternative, Mengapa tidak?: Buku Pintar Sekolah Alam, Homschooling, dan Anak Berkebutuhan Khusus, (Jakarta: Diva press, 2010), 72

${ }^{12}$ Ali Muhtadi, Pendidikan dan Pembelajaran, 9 
c. Meningkatkan kreativitas, kemampuan berfikir, dan sikap serta mengembangkan kepribadian peserta didik.

d. Membina dan mengembangkan hubungan baik antara orang tua dan anak didik sehingga tercipta keluarga yang harmonis.

e. Mengatasi keterbatasan, kelemahan, dan hambatan emosional anak didik sehingga anak didik tersebut berhasil belajar yang optimal.

f. Mengembangkan bakat, potensi, dan kebisaan-kebiasaan belajar anak didik secara alamiah.

g. Mempersiapkan kemampuan peserta didik dalam aspek pengetahuan, keterampilan, dan sikap untuk melanjutkan studi pada jenjang yang lebih tinggi.

h. Membekali peserta didik dengan kemampuan memecahkan masalah lingkungan sesuai tingkat perkembangannya demi kelulusan hidupnya di masa depan. ${ }^{13}$

Kesimpulan dari tujuan homeschooling di atas adalah melayani peserta didik dalam penyelesaian pendidikan dengan menciptakan kondisi lingkungan belajar yang kondusif, dalam konteks kehidupan nyata, mengatasi keterbatasan, kelemahan, dan hambatan emosional yang dihadapi anak, serta mengembangkan bakat, potensi yang dimiliki dengan membekali anak untuk mampu memecahkan masalah lingkungannya.

\section{Macam-macam Homeschooking}

Hanaco, mengklasifikasikan homeschooling sesuai dengan tujuan, kondisi dan kebutuhan masing-masing orang tua atau keluarga. Jenis-jenis homeschooling adalah: 1). Homeschooling tunggal; 2). Homeschooling majemuk; 3). Homeschooling komunitas. ${ }^{14}$

${ }^{13}$ Seto Mulyadi, Homeschooling Keluarga Kak-Seto, 15

${ }^{14}$ Indah hanaco, I Love Homeschooling, 6 


\section{a) Homeschooling Tunggal}

Homeschooling tunggal adalah format sekolah rumah yang dilaksanakan oleh orang tua dalam satu keluarga tanpa bergabung dengan homeschooling lainnya. Homeschooling ini adalah pendidikan berbasis rumah, dengan orng tua sebagi penanggung jawab aktif serta fokus pada kepentingan dan kebutuhan anak-anaknya. ${ }^{15}$ Ada beberapa kelebihan penerapan homeschooling tunggal, diantaranya: 1). adanya kebutuhan-kebutuhan khusus yang ingin dicapai keluarga homeschooling tunggal yang tidak dapat diketahui atau dikompromikan dengan keluarga homeschooling lainnya; 2). lokasi atau tempat tinggal yang tidak memungkinkan berhubungan dengan homeschooling lainnya; 3). memiliki fleksibilitas tinggi, tempat, bentuk, dan waktu belajar bisa disepakati oleh pengajar dan peserta didik. ${ }^{16}$

Selain beberapa kelebihan-kelebihan yang telah disebutkan di atas, ada beberapa kelemahan dalam homeschooling tunggal, diataranya: 1). tidak ada tempat untuk bersosialisasi, terutama bagi anak yang memerlukan tempat mengekspresikan diri sebagai syarat pendewasaan kepribadian anak; 2). orang tua harus menyelenggarakan sendiri penilaian terhadap hasil pendidikan atau mengusahakan sendiri kesetaraan dengan standar pendidikan yang ditetapkan oleh homeschooling komunitas yang ada. Pendapat tersebut didukung oleh Kembara, yang mengatakan bahwa kelemahan yang dimiliki homeschooling tunggal yaitu tidak adanya mitra (partner) untuk saling mendukung, berbagi atau membandingkan keberhasilan dalam proses belajar. ${ }^{17}$

Sebagaimana yang telah diterapkan oleh beberapa selebritis muda, mereka cenderung mengambil tipe homeschooling tunggal karena kesibukan

\footnotetext{
15 Indah hanaco, I Love Homeschooling, 5

16 Seto Mulyadi, Homeschooling Keluarga Kak-Seto, 20

17 Maulia D. Kembara, Panduan Lengkap Homeschooling, (Bandung: PT Syaamil Cipta Media, 2007), 29
} 
mereka yang luar biasa. Mereka menyewa seorang guru yang datang ke rumah beberapa kali dalam seminggu atau yang bersangkutan datang ke lokasi selebritis beraktivitas, misalnya di tempat syuting. ${ }^{18}$ Dengan demikian, jelaslah bahwa homeschooling tunggal sengaja diterapkan oleh orang tua dengan tidak bergabung dengan homeschooling lainnya serta dalam penerapan proses belajar mengajar waktu disesuaikan dengan kondisi dan kebutuhan anak.

\section{b) Homeschooling Majemuk}

Homeschooling majemuk adalah format sekolah rumah yang dilaksanakan oleh satu orang tua, dua atau lebih keluarga untuk kegiatan tertentu. Sementara, kegiatan inti atau pokok tetap dilaksanakan oleh orang tua masing-masing. ${ }^{19}$ Kelebihan penerapan homeschooling majemuk adalah adanya kebutuhan-kebutuhan yang sama yang dapat dikompromikan oleh beberapa keluarga dalam kegiatan bersama, contohnya: kurikulum dari konsorsium, asosiasi, organisasi, lokal, nasional atau internasional dengan bahasa tertentu, kegiatan olah raga tertentu (misalnya, keluarga atlet tenis) yang menuntut jadwal kegiatan belajar disiplin tertentu, mendalami salah satu keahlian musik atau seni tertentu dan kegiatan agama tertentu.

Selain ada beberapa kelebihan yang telah disebutkan di atas terdapat beberapa kelemahan dalam penerapan homeschooling majemuk, diantaranya adalah perlu adanya kompromi dan fleksibilitas untuk menyesuaikan jadwal, suasana dan fasilitas tertentu yang dapat menampung beberapa anak dalam junlah keluarga pada saat kegiatan dilaksanakan, serta harus mendapatkan pengawasan dan bimbingan atau dilatih oleh seorang ahli dalam bidang tertentu, sehingga anak diharuskan menyesuaikan diri dengan

\footnotetext{
${ }^{18}$ Maulia D. Kembara, Panduan Lengkap Homeschooling, 31

${ }^{19}$ Indah hanaco, I Love Homeschooling, 6
} 
lingkungannya dan orang tua harus mengusahakan sendiri kesetaraan dengan standar yang ditetapkan oleh komunitas homeschooling.

Senada dengan pendapat di atas, Kembara mengatakan bahwa ada beberapa kelemahan penerapan homeschooling majemuk, salah satunya adalah keharusan untuk melakukan kompromi dengan peserta lain dalam hal jadwal, suasana, fasilitas dan pilihan kegiatan. Hal ini dikarenakan setiap orang tua memiliki kesibukan dan agenda berbeda. sehingga waktu pendampingan anak-anak harus disesuaikan secara optimal. ${ }^{20}$

Dari uraian di atas, dapat disimpulkan bahwa homeschooling majemuk merupakan gabungan dua atau lebih pelaku homeschooling yang sama-sama mengkompromikan kegiatan belajar untuk anak-anaknya yang sesuai dengan kebutuhan, kegiatan dan kepentingan yang bisa dilakukan bersamasama dengan pelaku homeschooling lainnya. Sementara itu, kegiatan inti atau pokok tetap dilaksanakan oleh orang tua masing-masing.

\section{c) Homeschooling Komunitas}

Homeschooling komunitas merupakan gabungan beberapa homeschooling majemuk yang menyusun dan menentukan silabus, serta bahan ajar bagi anak-anak homeschooling, termasuk menentukan beberapa aktivitas dasar (olahraga, musik atau seni dan bahasa) serta fasilitas tempat. ${ }^{21}$

Kembara mengatakan bahwa homeschooling komunitas memiliki konsep yang lebih terstruktur dan lengkap untuk pendidikan akademik, pembangunan akhlak mulia, pencapaian hasil belajar dan ruang gerak sosialisasi peserta didik lebih luas. ${ }^{22}$

Selain kelebihan di atas ada juga kelemahan penerapan homeschooling komunitas, diantaranya:

\footnotetext{
20 Maulia D. Kembara, Panduan Lengkap Homeschooling, 32

21 Satmoko Budi Santoso, Sekolah alternative, mengapa tidak?, 73

22 Maulia D. Kembara, Panduan Lengkap Homeschooling, 32
} 
1) orang tua harus melakukan kompromi untuk menyesuaikan jadwal, suasana dan fasilitas tertentu yang dapat menampung beberapa anak dari beberapa keluarga pada saat kegiatan dilaksanakan bersamasama.

2) harus mendapatkan pengawasan professional.

3) anak-anak dengan kegiatan khusus harus mampu menyesuaikan dengan lingkungannya dan mau menerima perbedaan perbedaan yang ada. ${ }^{23}$

Dari uraian di atas dapat disimpulkan bahwa homeschooling komunitas adalah merupakan gabungan dari beberapa homeschooling majemuk yang bersama-sama mengkompromikan kegiatan belajar untuk anak-anaknya sesuai dengan kebutuhan dan kepentingan yang bisa dilakukan bersamasama yang dilaksanakan pada waktu tertentu. Dapat ditarik kesimpulan bahwa terdapat tiga jenis homeschooling yaitu homeschooling tunggal yang penerapan pelaksanaannya dilakukan oleh satu keluarga dengan tidak bergabung dengan keluarga yang lain,

Homeschooling majemuk yang penerapannya merupakan penggabungan dari beberapa pelaku homeschooling, dan homeschooling komunitas adalah penggabungan dari beberapa homeschooling majemuk yang penerapannya dilaksanakan pada waktu tertentu.

\section{Homeschooling Dalam Prespektif Islam}

Mengutip perkataan imam Al-Ghazali tentang sangat berharganya anak dalam kehidupan:

"Anak itu amanah Allah bagi kedua orangtuanya, hatinya bersih bagaikan mutiara yang indah bersahaja, bersih dari setiap lukisan dan gambar. Ia menerima setiap yang dilukiskan, dan cenderung ke arah apa saja yang diarahkan kepadanya. Jika ia dibiasakan belajar dengan baik ia

${ }^{23}$ Maulia D. Kembara, Panduan Lengkap Homeschooling, 32 
akan tumbuh menjadi baik, beruntung di dunia dan di akhirat. Kedua orangtuanya, semua gurunya, pengajar dan pendidiknya sama-sama mendapat pahala. Dan jika ia dibiasakan melakukan keburukan dan diabaikan sebagaimana mengabaikan hewan, ia akan celaka dan rusak, dan dosanya menimpa pengasuh dan orang tuanya" ${ }^{24}$

Anak adalah milik Allah SWT. Ia dititipkan pada orang tua untuk diasuh, dididik dan dijaga agar tidak tersentuh api neraka. Allah SWT berfirman:

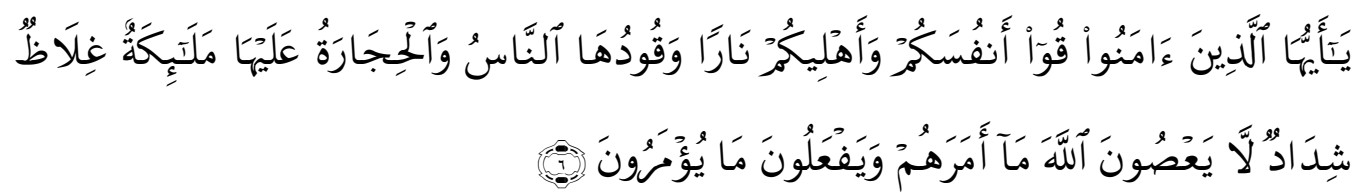

"Hai orang-orang yang beriman, peliharalah dirimu dan keluargamu dari api neraka yang bahan bakarnya adalah manusia dan batu; penjaganya malaikat-malaikat yang kasar, keras, dan tidak mendurhakai Allah terhadap apa yang diperintahkan-Nya kepada mereka dan selalu mengerjakan apa yang diperintahkan" (QS. Al-Tahrim: 6) ${ }^{25}$

Itu berarti, anak adalah amanah Allah SWT. Karenanya ia seharusnya dididik untuk menjadi sebagaimana yang Allah SWT kehendaki, yaitu untuk menjadi hamba Allah SWT dan menjadi khalifah di muka bumi. Allah berfirman:

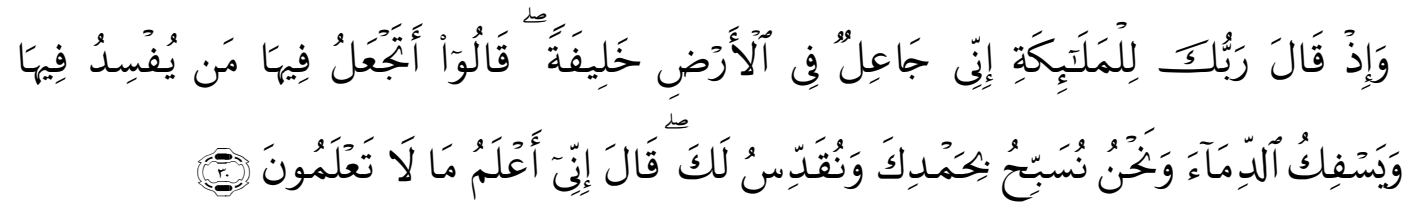

Ingatlah ketika Tuhanmu berfirman kepada para malaikat: "Sesungguhnya Aku hendak menjadikan seorang khalifah di muka bumi." mereka berkata: "Mengapa Engkau hendak menjadikan (khalifah) di bumi itu orang yang akan membuat kerusakan padanya dan menumpahkan darah, padahal kami senantiasa bertasbih dengan

24 Yakhsyallah Mansur, Tanggung Jawab Orang Tua dalam Pendidikan Anak, https://groups.google.com/forum/\#!msg/daarut-tauhiid/0o7wzZ5r-ws/AgdoSIN1wXcJ, (8 Juli 2008), 1

${ }^{25}$ Departemen Agama RI, Al-Qur'an dan Terjemahannya, 560. 
memuji Engkau dan mensucikan Engkau?" Tuhan berfirman: "Sesungguhnya Aku mengetahui apa yang tidak kamu ketahui." (QS.Al Baqarah : 30). ${ }^{26}$

Menjadi hamba Allah SWT berarti anak harus dididik untuk senantiasa tunduk dan taat pada syariat (aturan) Allah SWT. Sedangkan menjadi khalifah di bumi artinya anak harus dididik agar mampu mengolah bumi dengan segala potensinya sesuai dengan syariat Allah SWT. Allah SWT juga memerintahkan agar orang tua mengantarkan anak menjadi orang-orang yang kuat dalam segala aspeknya. Allah SWT berfirman:

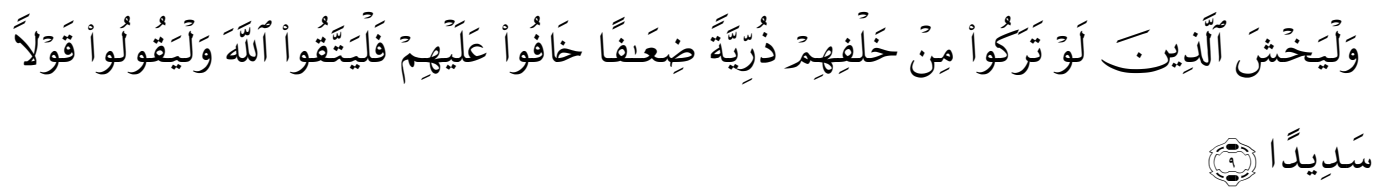

Dan hendaklah takut kepada Allah orang-orang yang seandainya meninggalkan dibelakang mereka anak-anak yang lemah, yang mereka khawatir terhadap (kesejahteraan) mereka. oleh sebab itu hendaklah mereka bertakwa kepada Allah dan hendaklah mereka mengucapkan perkataan yang benar. (QS. An Nisaa : 9). ${ }^{27}$

Setiap orang tua yang memahami bahwa anak adalah karunia dan amanah dari Allah SWT, pasti akan memberikan dan melakukan 'yang terbaik' untuk anaknya: yang terbaik dalam masa kehamilan, yang terbaik dalam masa menyusui (radha'ah) -yaitu dengan memberi ASI eksklusif hingga 6 bulan dan melanjutkannya hingga sempurna 2 tahun-, yang terbaik dalam pengasuhan (hadlanah), dan yang terbaik dalam pendidikan (tarbiyah).

Rasulullah. SAW bersabda:

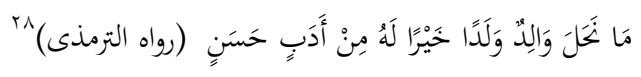

“Tidak ada pemberian orang tua kepada anak yang lebih utama daripada pendidikan yang baik" (HR. Al-Tirmidzi). ${ }^{29}$

${ }^{26}$ Departemen Agama RI, Al-Qur'an dan Terjemahannya, 6.

27 Departemen Agama RI, Al-Qur'an dan Terjemahannya, 78

28 Imam al-Hafizh Abu Isa Muhammad bin Isa bin Saurah bin Musa bin ad-Dahhak asSulami at-Tirmizi, Sunan Al-Tirmidzi, juz 7, 206 
Dalam Islam dijelaskan, anak itu dilahirkan dalam keadaan fitrah. Jika orang tua membiasakan anak untuk melakukan kebaikan, maka dia akan tumbuh menjadi baik dan menjadi orang yang bahagia di dunia dan akherat. Sebaliknya, jika orang tua membiasakan anak dengan keburukan serta menelantarkannya seperti hewan ternak, maka dia akan menjadi orang yang celaka dan binasa. Keadaan fitrahnya akan senantiasa siap untuk menerima yang baik atau yang buruk dari orang tua atau pendidiknya.

Rasulullah SAW. bersabda:

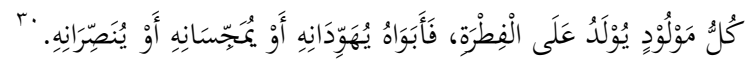

"Setiap anak yang lahir dilahirkan di atas fitrah, maka kedua orang tuanya lah yang menjadikannya Yahudi, Majusi, atau Nasrani." 31

Pendidikan dalam rumah sangat penting, karena merupakan pondasi awal atau merupakan pilar utama dalam tumbuh kembang anak. Siapapun yang kelak menjadi pedagang, politikus, dosen, peneliti, arsitek, tentara atau apapun, awalnya tentu sangat bergantung pada pola pendidikan di rumah. Itu berarti bahwa peran orang tua adalah hal yang paling utama kerena tidak jarang, orang tua tidak bisa bertemu dengan anak dengan waktu kerja yang begitu padat.

Menurut Zakiah Daradjat tanggung jawab pendidikan Islam yang dibebankan orang tua sekurang-kurangnya adalah:

a. Memelihara dan membesarkan anak. Ini adalah bentuk yang paling sederhana dari tanggung jawab setiap orang tua dan merupakan dorongan alami untuk mempertahankan kelangsungan hidup manusia.

${ }^{29}$ Yakhsyallah Mansur, Tanggung Jawab Orang Tua, 1

30 Muhammad bin Hibban bin Ahmad bin Hibban bin Muadz bin Ma'bad bin Sahid atTamimy, Shahih Ibnu Hibban bi Tartib Ibni Balban, juz 1, (Beirut: Dar al-Fikr, tt), 336

31 . Yakhsyallah Mansur, Tanggung Jawab Orang Tua, 1 
b. Melindungi dan menjamin kesamaan, baik jasmaniah maupun rohaniah, dari berbagai gangguan penyakit dan dari penyelewengan kehidupan dan tujuan hidup yang sesuai dengan falsafat hidup dan agama yang dianutnya.

c. Memberi pengajaran dalam arti yang luas sehingga anak memperoleh peluang untuk memiliki pengetahuan dan kecakapan seluas dan setinggi mungkin yang akan dicapainya.

d. Membahagiakan anak, baik dunia maupun akherat, sesuai dengan pandangan dan tujuan hidup muslim ${ }^{32}$

Orang tualah paling utama berkepentingan mendidik putra-putrinya ke arah yang baik dan memberi bekal berbagai pengetahuan adab dan moral agar mereka terbimbing menjadi anak-anak yang dapat dibanggakan kelak di hadapan Allah.

Sabda Rasuulullah. SAW:

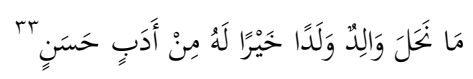

"Tiada suatu pemberian pun yang lebih utama dari orang tua kepada anak-anaknya, selain pendidikan yang baik"34

Dalam hadist di atas, dijelaskan bahwa hal yang paling utama yang harus diperhatikan bagi orang tua adalah pendidikan anak. Orang tua diwajibkan untuk menanamkan pendidikan sejak dalam kandungan sampai anak lahir karena pendidikan atau ilmu pengetahuan merupakan tiang kehidupan yang nantinya dapat menunjukkan jalan hidup di dunia dan akherat. Selain itu pendidikan merupakan pemberian yang lebih utama dari yang lainnya.

Pendapat di atas didukung oleh Locke, yang mengatakan bahwa:

32 Zakiah Daradjat, Perawatan Jiwa Untuk Anak-anak (Jakarta ; Bulan Bintang, 1989), 32

${ }^{33}$ Imam at-Tirmizi, Sunan Al-Tirmidzi, juz 7,( Beirut: Dar al-Kutub al-Ilmiyah,tt), 206.

34 Zakiah Daradjat, Perawatan Jiwa, 32. 
Jiwa anak bagaikan tabularasa, sebuah meja lilin yang dapat ditulis dengan apa saja sesuai dengan keinginan si pendidik. Tidak ada bedanya dengan sehelai kertas putih yang ditulis dengan tinta yang berwarna apa saja, merah atau hitam. ${ }^{35}$

Jadi, pemberian yang lebih utama terhadap anak adalah pendidikan. Orang tua dan pengajar merupakan penentu anak kelak di kemudian hari akan menjadi seperti apa. Ketika anak diajarkan baik maka anak akan baik tetapi ketika anak diajarkan buruk maka anak akan buruk. Oleh karena itu pendidikan harus lebih diutamakan. Hadits tersebut juga menjelaskan bahwa tiada suatu pemberian apapun yang paling berharga dari orang tua kepada anaknya selain pendidikan, yang lebih baik. Hal ini berkaitan dengan tiga perkara ketika orang meninggal, yaitu amal jariyah, ilmu yang bermanfaat, dan yang ketiga anak yang sholeh yang selalu mendoakan orang tuanya. Dengan demikian, pendidikan yang diberikan kepada anak haruslah pendidikan yang terbaik. ${ }^{36}$

Mendidik anak bukanlah hal yang mudah, bukan pula pekerjaan yang dapat dilakukan secara serampangan serta bukan pada hal yang bersifat sampingan. Mendidik dan mengajar anak sama kedudukannya dengan kebutuhan pokok dan kewajiban yang harus dipenuhi. Bahkan, mendidik dan mengajar anak merupakan tugas yang harus dan mesti dilakukan oleh setiap orang, karena perintah mengenainya datang dari Allah sebagaimana terdapat dalam al-Qur'an:

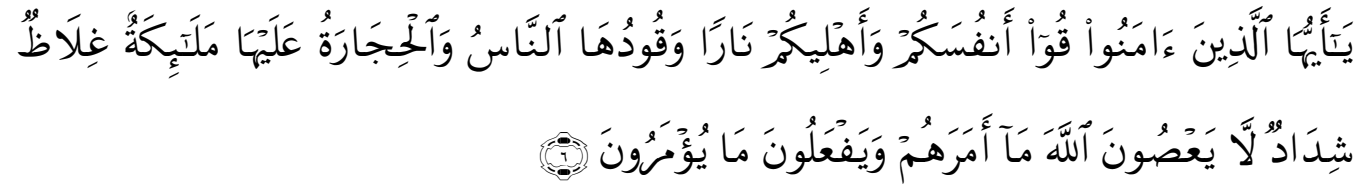

35 John Lock, dalam Rosalia Yenita Widyaningrum, john locke dan tabula rasa, dalam http://rosaliayenita.blogspot.com /2013/01/john-locke-dan-tabula-rasa.html

36 Rosalia Yenita Widyaningrum, john locke dan tabula rasa, dalam http: // rosaliayenita.blogspot.com /2013/01/john-locke-dan-tabula-rasa.html 
" Hai orang-orang yang beriman, peliharalah dirimu dan keluargamu dari api neraka yang bahan bakarnya adalah manusia dan batu; penjaganya malaikat-malaikat yang, keras, tidak mendurhakai (perintah) Allah terhadap apa yang di perintahkan Nya kepada mereka dan selalu mengerjakan apa yang diperintahkan (QS. Al-Tahrim :6). ${ }^{37}$

Dalam tafsir Ibnu katsir, 38 ayat ini semakna dengan hadits yang diriwayatkan oleh Ahmad, Abu Dawud dan Al-tirmidzi dari al-rabi' bin Sabrah, dari bapaknya ia mengatakan bahwa Rasulullah bersabda:

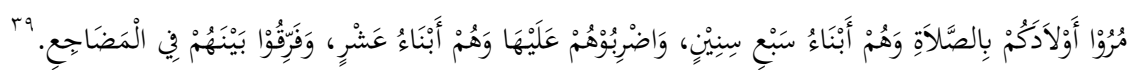

"Perintahkanlah anak-anak kalian untuk shalat ketika mereka berusia tujuh tahun, dan pukullah mereka jika mereka tidak mengerjakan shalat pada usia sepuluh tahun, dan (pada usia tersebut) pisahkanlah tempat tidur mereka."

Dalam ayat dan hadits tersebut dijelaskan bahwa prioritas yang paling utama bagi orang-orang yang beriman adalah menjaga diri dan keluarga. Kalau ingin berbuat sesuatu, kita perbaiki dahulu diri dan selamatkan keluarga.

Ada beberapa keluarga yang menerapkan homeschooling dengan alasan adanya ketidak puasan terhadap pembelajaran religi yang diperoleh di sekolah dan kekhawatiran orang tua terhadap pengaruh luar terhadap anaknya, sehingga ada beberapa orang tua yang lebih memilih homeschooling sebagai tempat pembelajaran anak. Dalam hal ini orang tua harus lebih serius menjadi figur dan suri tauladan bagi anak-anaknya, jangan sampai anak kecewa dengan figur orang tuanya.

Ilmu sangat penting dalam kehidupan manusia baik selama hidup di dunia maupun di akherat. Jadi, orang tua wajib mendidik putra-putrinya

${ }^{37}$ Departemen Agama RI, Al-Qur'an dan Terjemahannya,560.

38 Syaikh Syafiurrahman al-Mubarakfuri, al-Misbah Fi Tahdzibi Tafsir Ibnu Katsir, terjemah Abu Ihsan al-Atsari, Shahih Tafsir Ibnu Katsir, Jilid IX, (Jakarta: Pustaka Ibnu Katsir, 2011), 188. 39 Sulaiman bin Al-Asy'as bin Ishak bin Basyir bin Syidad bin Amar Al-Azdi As-Sijistani, sunan Abu Dawud, juz 2, Hadits Nomer 418, 88. 
dengan pendidikan yang sebaik mungkin, sehinggga anak akan medapatkan ilmu yang bermanfaat yang dapat membawa anak menjadi orang yang berguna di dunia dan selamat di akhirat, sebagaimana disebutkan dalam AlQur'an:
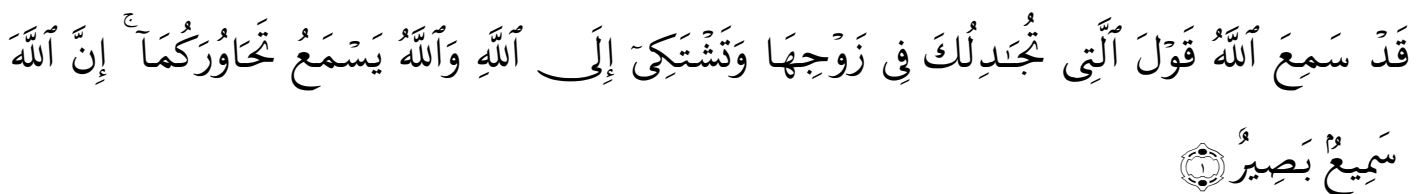

\begin{abstract}
“Dan apabila dikatakan (kepadamu): Berdirilah, maka berdirilah, niscaya Allah akan meninggikan orang-orang yang beriman diantaramu dan orang-orang yang diberi ilmu pengetahuan beberapa derajad dan Allah maha mengetahui apa yang kamu kerjakan" (QS. AlMujadilah : 1). ${ }^{40}$
\end{abstract}

\title{
Penutup
}

Model belajar homeschooling merupakan model belajar yang tidak dilakukan di sekolah formal, dimana sebuah keluarga memilih untuk bertanggung jawab sendiri atas pendidikan anaknya dengan menggunakan rumah sebagai basis pendidikannya. Namun demukian, homeschooling sama sekali tidak bertentangan dengan Islam, karena pada dasarnya, menuntut ilmu bisa dilakukan dimana saja, kapan pun dan kepada siapapun tidak dibatasi oleh waktu, usia dan jenis kelamin. Oleh sebab itu, pendidikan bagi anak sangat diutamakan dan orang tua berkewajiban memelihara anak-anaknya dengan cara mendidik, memberikan pekerti, dan mengajarkannya akhlaq-akhlaq mulia, serta menghindarkannya dari teman-teman yang berbudi pekerti buruk.

${ }^{40}$ Departemen Agama RI, Al-Qur'an dan Terjemahannya, 542. 


\section{DAFTAR PUSTAKA}

Abe, A. Saputra, Rumahku Sekolahku. Panduan Bagi Orang Tua Untuk Menciptakan Homeschooling: (Yogyakarta: Graha Pustaka, 2007)

Budi Santoso, Satmoko. Sekolah Alternative, Mengapa tidak?: Buku Pintar Sekolah Alam, Homschooling, dan Anak Berkebutuhan Khusus, (Jakarta: Diva press, 2010)

Daradjat, Zakiah. Perawatan Jiwa Untuk Anak-anak (Jakarta ; Bulan Bintang, 1989).

Departemen Agama RI, Al-Qur'an dan Terjemahannya, (Bandung: PT Sygma Examedia Arkanleema, 2009).

Hanaco, Indah. I Love Homeschooling, Segala Sesuatu yang Harus Diketahui Tentang Homeschooling (Jakarta: PT. Gramedia Pustaka Utama, 2012)

Kembara, Maulia D, Panduan Lengkap Homeschooling, (Bandung: PT Syaamil Cipta Media, 2007)

Muba>rakfuri (al), Syaikh Syafiurrahma>n, al-Misbah\} Fi Tahdzibi Tafsir Ibnu Katsir, terjemah Abu Ihsan al-Atsari, Shahih Tafsir Ibnu Katsir, Jilid IX, (Jakarta: Pustaka Ibnu Katsir, 2011).

Mulyadi, Seto. Homeschooling Keluarga Kak-Seto: Mudah, Murah, Meriah, dan Direstui Pemerintah. (Bandung: Kaifa PT Mizan Pustaka, 2007)

Sumardiono H. Home Schooling A Lear For Better Learning. (15 Maret 2012)

Tamimy (at), Muhammad bin Hibban bin Ahmad bin Hibban bin Muadz bin Ma'bad bin Sahid, Shahih Ibnu Hibban bi Tartib Ibni Balban, juz 1, (Beirut: Dar al-Fikr, tt).

Tirmizi (al), Imam al-Hafizh Abu Isa Muhammad bin Isa bin Saurah bin Musa bin ad-Dahhak as-Sulami, Sunan Al-Tirmidzi, juz 7, tt 